ments carried out in Hertfordshire, he did not live to see the completion of the first commercial "telpher line" now being erected at Glynder in Sussex.

The building of houses on sanitary principles interested him largely, and the Sanitary Protection Associations in Edinburgh and in London owed their existence to his initiation, and their success was largely due to his constant exertions. His article on "Bridges" in the "Encyclopædia Britannica," his book on "Healthy Houses," and his primer on "Magnetism and Electricity;" are well known to scientific readers, but not perhaps to the readers of his numerous articles in the quarterly reviews and monthly magazines, the last of which was his recent article on "Telpherage" in Good Words. His numerous scientific papers published since 1864 are to be found in the Proceedings of the British Association, the Philosophical Magazine, the Proceedings and Transactions of the Royal Societies of London and Edinburgh, the Fournal of the Society of Arts, the American Fournal of Science, and the Fournal of the Society of 'Telegraph Engineers.

Technical education much interested him long before it acquired its present interest for the public, and he presided at meetings of the Society of Arts and other societies when papers on that subject were brought forward. As a director of the Watt Institute in Edinburgh for several years he helped to advance technical education in Scotland.

He was an enthusiastic admirer of ability in other men, and he was especially warm in his encouragement of beginners, whether they were his own pupils or not. To gain his help it was only necessary to let him see that it was anxiously wished for, and that the recipient was not likely to make a mean use of it. He had marked dramatic power, and the plays acted in his drawing-room will long be remembered by his friends; while to his conversation, his general reading and wide sympathies gave a charm which was as powerfully felt as it is now regretfully remembered by all who were fortunate enough to know him.

THE GEOLOGICAL SURVEY OF BELGIUM

$A$ LI who are interested in the careful and methodical A investigation of the geological structure of the European continent will be sorry to learn that the Belgian Chamber of Representatives has cut down the vote for the prosecution of the detailed Geological Survey of Belgium so seriously as practically to suspend the work. It is miserable to see personal dislikes, religious differences and political antagonism imported into the discussion of a scientific project. Every competent witness must bear testimony to the minute fidelity and conscientious labour with which M. Dupont and his staff have carried out their Survey. If any fault can be found with his maps it is that they are too complete. They give more information than any ordinary reader can assimilate. Each sheet, indeed, is a detailed treatise on the area which it depicts. There are certainly no such elaborately exhaustive maps published in any other country; and Belgium may justly boast that she has led the way in an important advance in the delineation of geological features. It is an open secret, however, that the official geologists have all along encountered the determined opposition of the "géologues libres" who were not so fortunate as to be entrusted with the control of the work. The Survey having been planned by the Liberal Ministry, and being stoutly supported by the authorities, has until now been able to hold on its course. Much time was, no doubt necessarily, spent by M. Dupont in perfecting his system of colour-printing, and the delay in the appearance of his maps, possibly also the difficulty found by the malcontents in understanding them, were used as arguments for a total reorganisation of the staff. The opposition has recently been renewed under the clerical Government now in power, and unfortunately with more success. From the published debate it is clear that the Minister in whose department the estimate for the Geological Map was prepared, and who was officially bound to support that estimate, sat still without speaking in its defence, and the House, taking this silence, no doubt, as an expression of the inclination of the new Government, cut down the vote. We are sure that this retrograde step will be regretted by all who wish well to the progress of science. Into the personal squabbles connected with the subject we have no wish to enter. But as a public act of unwisdom the vote of the House of Representatives will, we hope, be rescinded and the prosecution of the Survey will be again allowed to proceed. If any fault is found with the way in which the map has been prepared, surely the Commission contains talent and energy enough to inquire into this and set matters right without practically bringing the Survey to a stand.

\section{THE CONGO}

THESE two welcome volumes from Mr. Stanley testify to the accelerated rate of events in these latter times. It is only twelve years since Livingstone died in the vain search for the sources of the Nile down by Lake Bangweolo, and under the belief that no river but the Nile could sweep past Nyangwe with such a breadth and volume as he found the Lualaba to have. He was not singular in cherishing such a belief; many geographers believed, like him, that the Congo could not fetch such a sweeping circuit, and that the Lualaba must make its way northwards in spite of differences of level and somehow add its waters to the Albert Nyanza. It is only eight years since Mr. Stanley dispersed the delusion, and solved the problem both of the Nile and the Congo; it is just about six years since he began operations as the agent of the International African Association. To judge from the narrative of his journey across the continent, there was no blacker part of the Black Continent than the river banks between Nyangwe and the Atlantic, and no more intractable people than many of the tribes through whom he and his men had to run the gauntlet. Yet already, aimost solely by his exertions, this most unpromising region has become "A land of settled government," at least on paper. It has engaged the continued attention of diplomatists from all the great States of the world for months, and is the subject of as many treaties as if it had been founded a century ago.

In reality, however, it is something more than a paper State. No one can read Mr. Stanley's narrative without being convinced that all along the river from Vivi to Stanley Falls there already exists what may fairly be regarded as an organised Government, carried on from some twenty-four stations as centres. But with the merely political aspects of this successful undertaking we cannot deal here. It is certainly an interesting experiment, both from a political and social point of view, this attempt to raise into a State a region not yet redeemed from savagery. What the ultimate result will be it is hard to say; on the one side a great mass of savagery, and on the other the most advanced European influences in politics, in commerce, in industry, in religion. For already we find bands of missionaries everywhere, and as among them are many men of prudence, tact, and ability, Mr. Stanley acts wisely in encouraging their efforts; they will certainly be of service in helping him to accomplish the object he has in view.

Without the aid of the latest applications of science, Mr. Stanley could never have succeeded in accomplishing all he has done in the brief period of six years. Steam has been of infinite service to him, and engineer-

I "The Congo, and the Founding of its Free State." By Henry M. Stanley. Two Vols. (London: Sampson Low and Co., 1885.) 
ing contrivances in many ways. His flotilla of steamers, some of them most ingeniously contrived for the special navigation of the Congo, may be said to have been everything to him in carrying out his work; and the Congo Free State may be fairly set down as another "triumph of steam." Mr. Stanley claims for the Congo Free State an area of over a million square miles and a population of $42,608,000$. As to the area, that is probably not far out; but the population seems to us excessive. Mr. Stanley reaches this great figure by generalising the density which he finds on the banks of the river itself. Between Stanley Pool and Stanley Falls, a distance of about rooo miles, and including part of the Biyerré and Kwa Rivers, he finds a population of 806,300 , and takes for granted that a similar density will prevail throughout the whole of the Congo Basin. This is very unlikely. In uncivilised countries the population naturally crowds itself along the river banks, and it would be very unsafe to calculate on finding regions at a distance from rivers equally well populated. Throughout the whole of the million square miles claimed by the Congo State only a few lines of exploration have as yet been run, though we know that as a whole it is probably the best-watered region in Africa, and possibly therefore the most thickly peopled. But the tendency among African geographers recently has been to reduce previous estimates of the population of Africa, and instead of 200 millions it is thought that 170 millions is one more likely to be nearer the mark. But all estimates, except for districts that have been settled for some time, are necessarily conjectural ; and even for Morocco the greatest difference exists between the estimates of different travellers.

On the Lower Congo the Free State has been able to secure only a comparatively narrow strip of territory on the north bank-enough, however, to give it the right of free navigation between the sea and Vivi, where the first series of cataracts begin. From Vivi upwards to Manyanga the State possesses territory on both sides, when France comes in and clams the whole of the right bank of the river to the Likona tributary in $\mathrm{I}^{\circ} \mathrm{S}$. lat. Thence the Free State expands into boundless and unknown regions, which we hope it will do its best to explore and open up to science as well as to commerce. The aim in the north has been evidently to draw the boundary of the

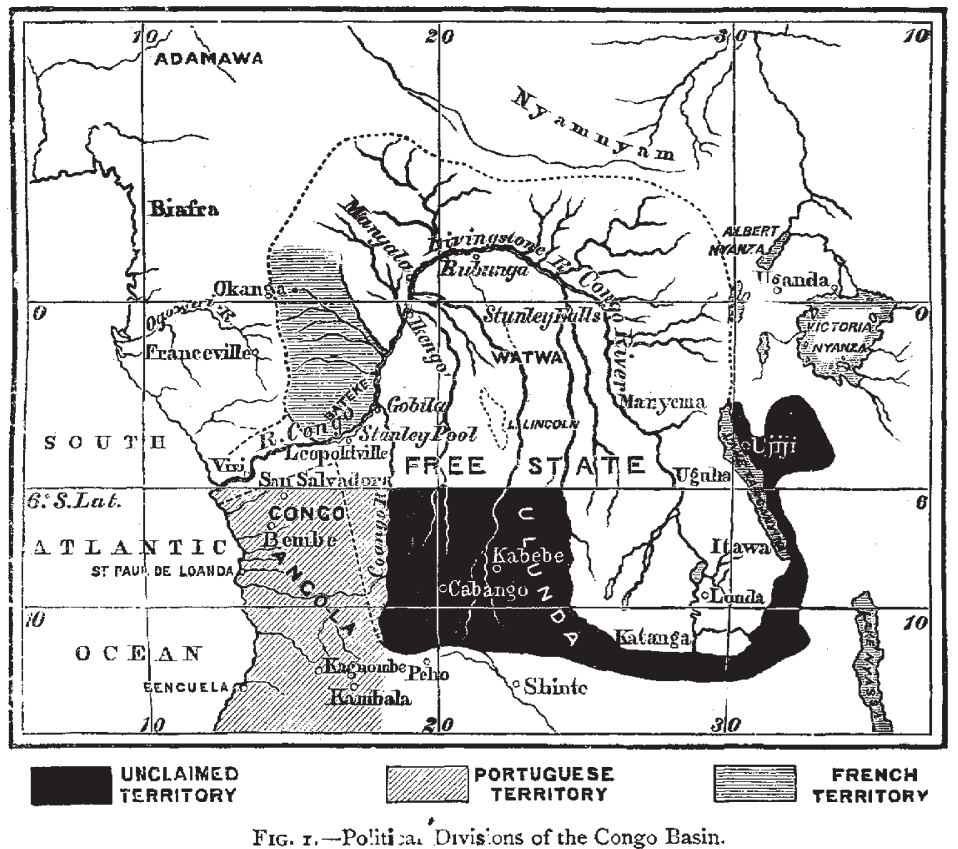

State between the basins of the Nile and the Congo. The western basin of the Upper Nile, no doubt, is fairly well known, but the region between that and the Upper Congo is just that part of Africa about which we know scarcely anything. The boundary on this side, therefore, has been drawn with the freedom of conjecture. All the rivers that are not known to send their waters to the Nile must, in Mr. Stanley's opinion, come down to the Congo, or, at least, ought to do so, and are made to conform with $\mathrm{Mr}$. Stanley's idea of what is right and proper, in the large map which accompanies his work. In spite of Dr. Junker's discovery of the water-shed which separates the Nepoko from the Welle, they are both made to send their waters southward to swell the magnificent Aruwimi. This may be so ; only actual exploration will decide the matter. It is mainly to settle this question that Dr. Lenz is preparing to proceed to the Upper Congo as leader of an expedition in to the region that lies between that region and the Upper Nile tributaries. And here we have one very beneficial result of the work which Mr. Stanley has done on the Congo. His numerous stations form so many starting-points for further exploration. They can be easily and rapidly reached from the West Coast, and through the agencies at their command, all the men and goods obtained necessary for the conduct of an expedition into the interior. If every station on the river were made the basis of further exploring work, one of the greatest blanks in our knowledge of Africa would soon be filled up. In the interest of the enterprise itselt this must be done. If the manifold products of the wonderful land over which Mr. Stanley is so enthusiastic are to be brought down to the river for shipment to the upper terminus of the future railway that is to convey them past the cataracts, it is evident that station after station must be pushed on into the interior. Among the white employés of the Association are many men of education and intelligence; and while their first duty is to look after the interests of the "Free State," these interests, instead of suffering, are likely to be advanced by a scientific knowledge of the country around the States. Already good meteorological work has been done at Vivi by Dr. Danckelmann, whose recently published 


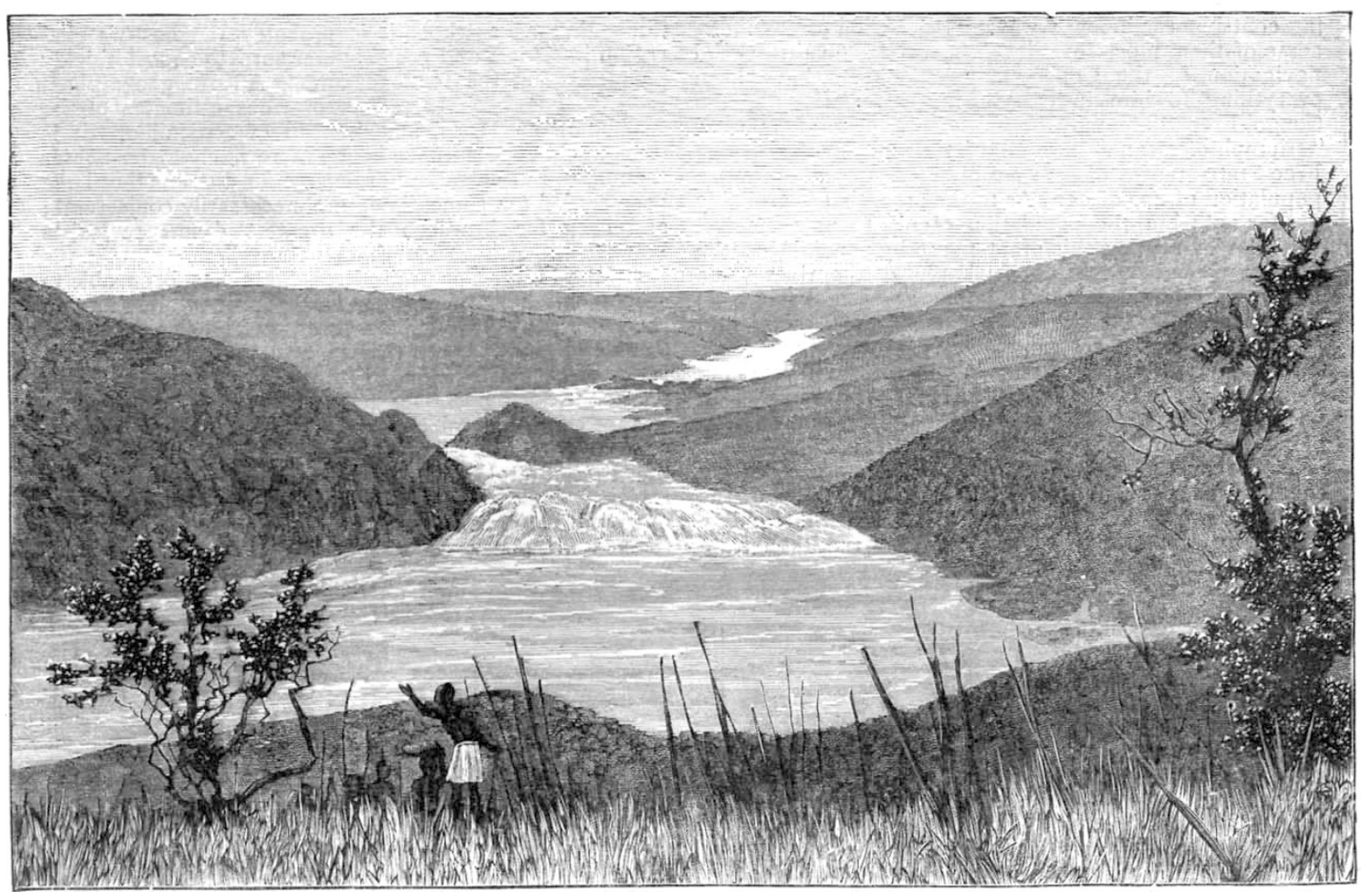

FIG. 2.-Yellala Falls from Left Bank.

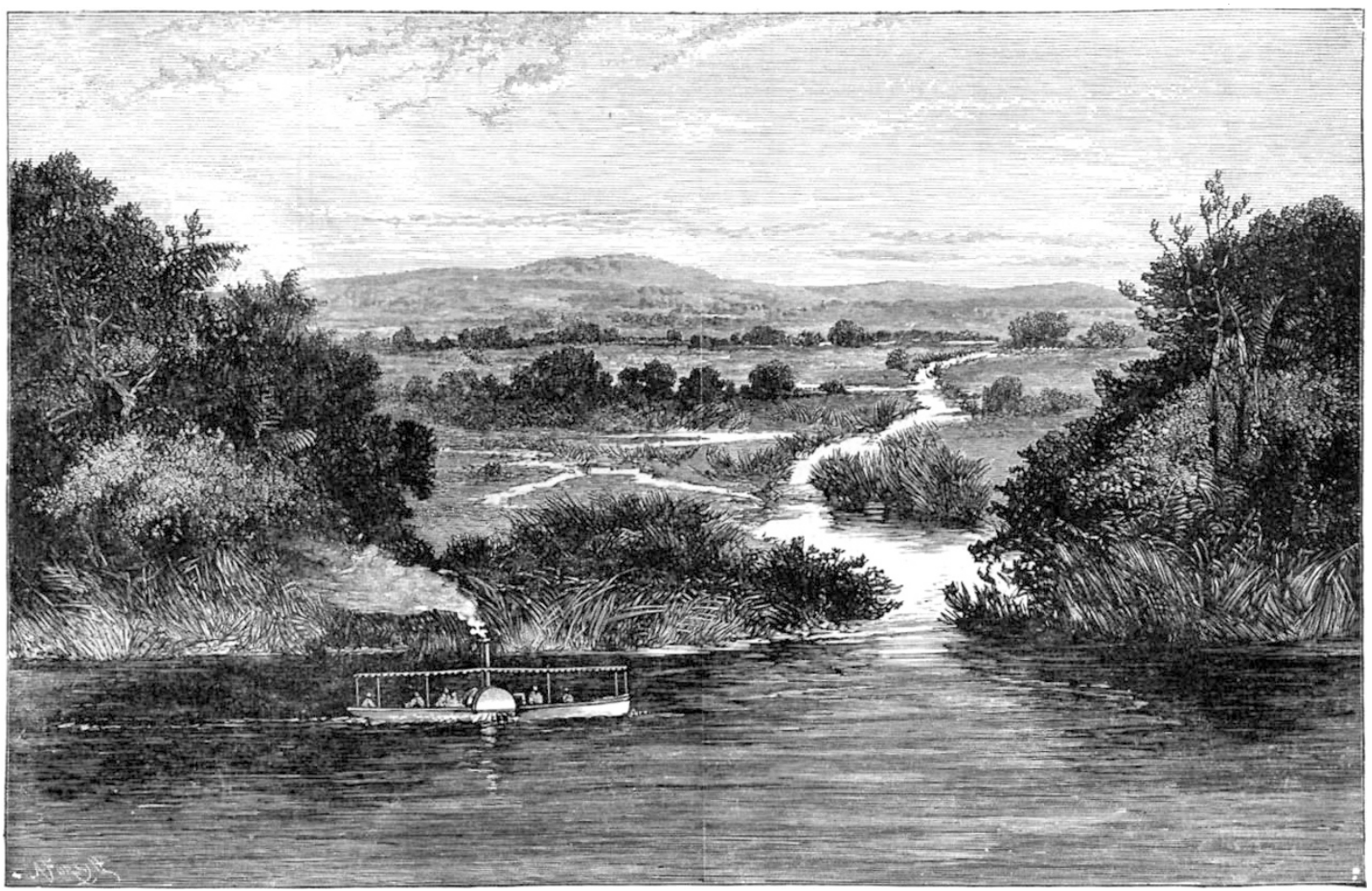

Fig. 3.-Head of Lake Leopold II. 
observations we reviewed some time ago. The utility of such observations is evident from the volumes before us. Mr. Stanley makes considerable use of them in his shapters on the Climate of the Congo. These chapters are of much interest ; they are written mainly with a view to show that, with reasonable precautions, Central Africa ought to be perfectly tolerable to the European constitution. What these precautions are he describes in minute detail. At the same time he admits that a lengthened residence in such tropical regions must in the end tell on

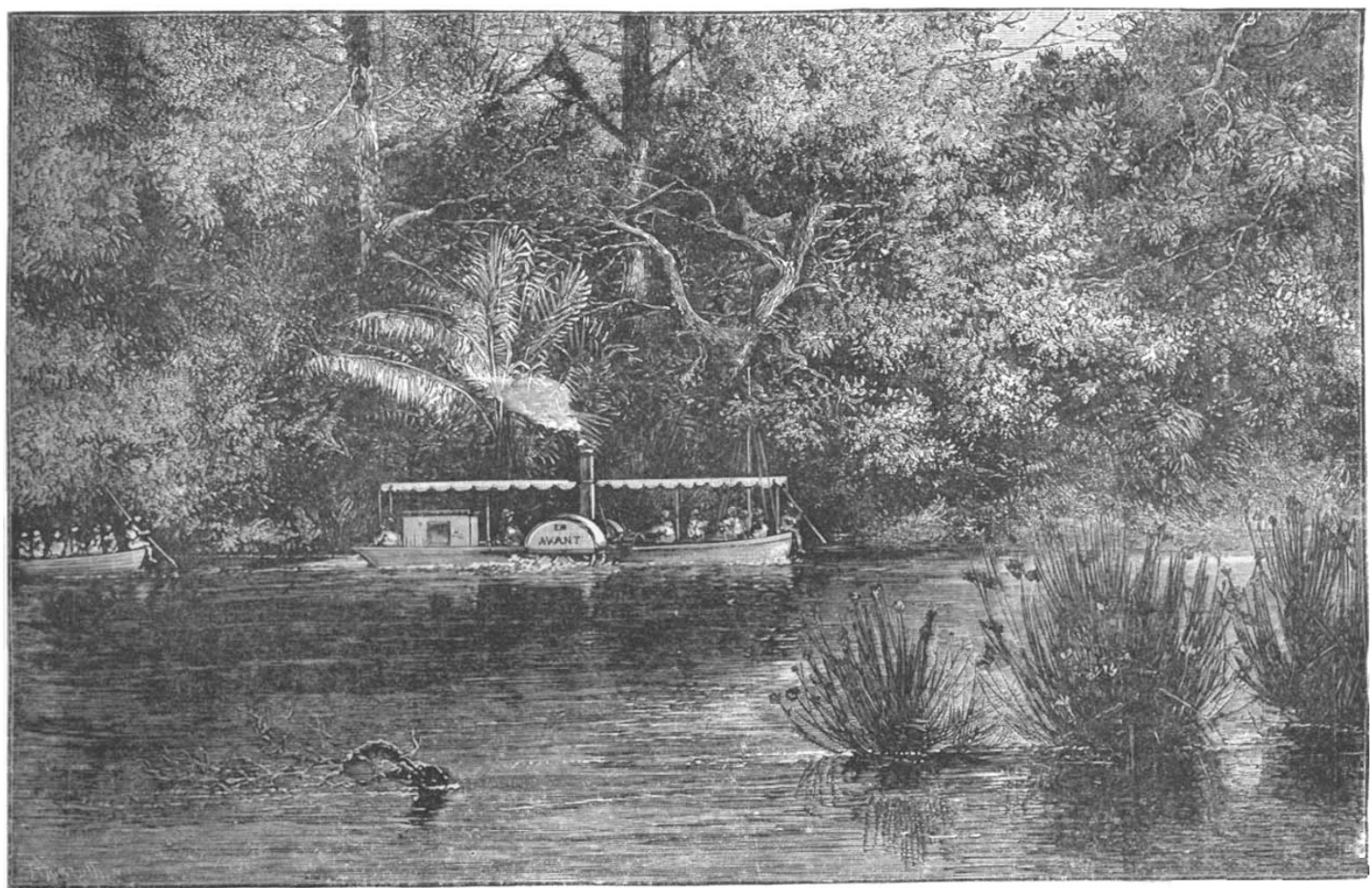

Fig. 4.-Banks of the Upper Congo.

the Europeans, and is only possible with a run home every eighteen months. Thus it is clear that if the resources of the Congo are to be developed, it must be by native labour, and there is therefore every inducement to reat the population humanely.

Of course, Mr. Stanley himself in his frequent journeys

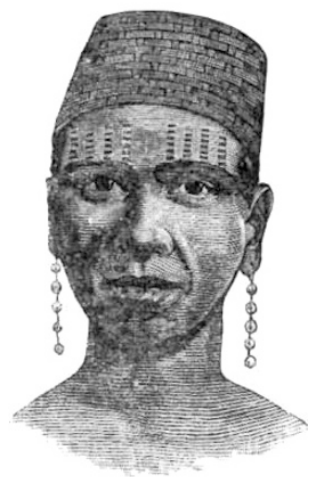

Fig. 5.-A Type of the Basoko.

up and down the river has added considerably to our knowledge of it. His original sketch of its course, made in one rush downwards, seems, however, to have been wonderfully accurate; though the hundreds of observations as to direction, altitude, depth, and width has enabled him to lay it down with much greater precision. It is to be hoped that the geology of the basin will be well worked out, and even from a "utilitarian" standpoint it might be useful for the Association to engage one or two competent men to work out the geology. The numerous cataracts on the lower as well as on the upper river prove that there is much here to interest the geologist. On the lower river, just where the great central plateau begins to shelve down to the coast, they are to be expected; but what is the exact geological explanation of the numerous cataracts on the upper river and its tributaries, as far south as Bangweolo, let us hope, will ere very long be explained. The banks of the river itself are in many places remarkably picturesque; indeed Mr. Stanley would make us believe that he thinks no other river is equal to it in this respect. Magnificent bluffs, he tells us, are met with in many places, and gorges that are almost cañons. At Stanley Pool and elsewhere the river has broadened out into lake-like reaches studded with islands, and at one place a few miles south of the equator there is a complicated offshoot of lakes and streams which reminds one of what is observed in so many places on the Central and Lower Amazon. This stretch has not, however, been completely explored, though Mr. Stanley's account of his journey up the Kwa and Mfini to Lake Leopold is one of the most interesting chapters in the volume. The Kwa discharges at about $3^{\circ} \mathrm{S}$. lat., and Lake Leopold, Mr. Stanley joins conjecturally to Lake Montumba, which is connected with the Congo at about fifty miles south of the equator. 
With regard to the volume of discharge of the Congo, from careful observations made at Stanley Pool, Mr. Stanley calculated that it reached $\mathrm{I}, 436,850$ cubic feet per second when the river at that point was at its lowest. During flood it rises, he believes, twelve feet higher, giving a volume of $2,529,600$ feet per second. If these estimates are correct, then Mr. Stanley calculates that the river discharges into the sea three million cubic feet of water per second.

Mr. Stanley's new work is so fully occupied with the details of the founding of his numerous stations, his dealings with chiefs and people, his road-making and other engineering enterprises, and the general work of engineering the enterprise, that there is little space left for geographical details. He does give a list of the products of the Upper Congo region, but as this is entirely from a commercial standpoint, its value to science is not great. The various species of palms, as might be expected, abound on the banks of the river and its islands, the oil-palm being the most valuable from a commercial point of view. Then come the various species of indiarubber plants, besides other gum-producing trees. Ivory, Mr. Stanley reckons only fifth in rank among the natural products of the Congo. He presumes that there are

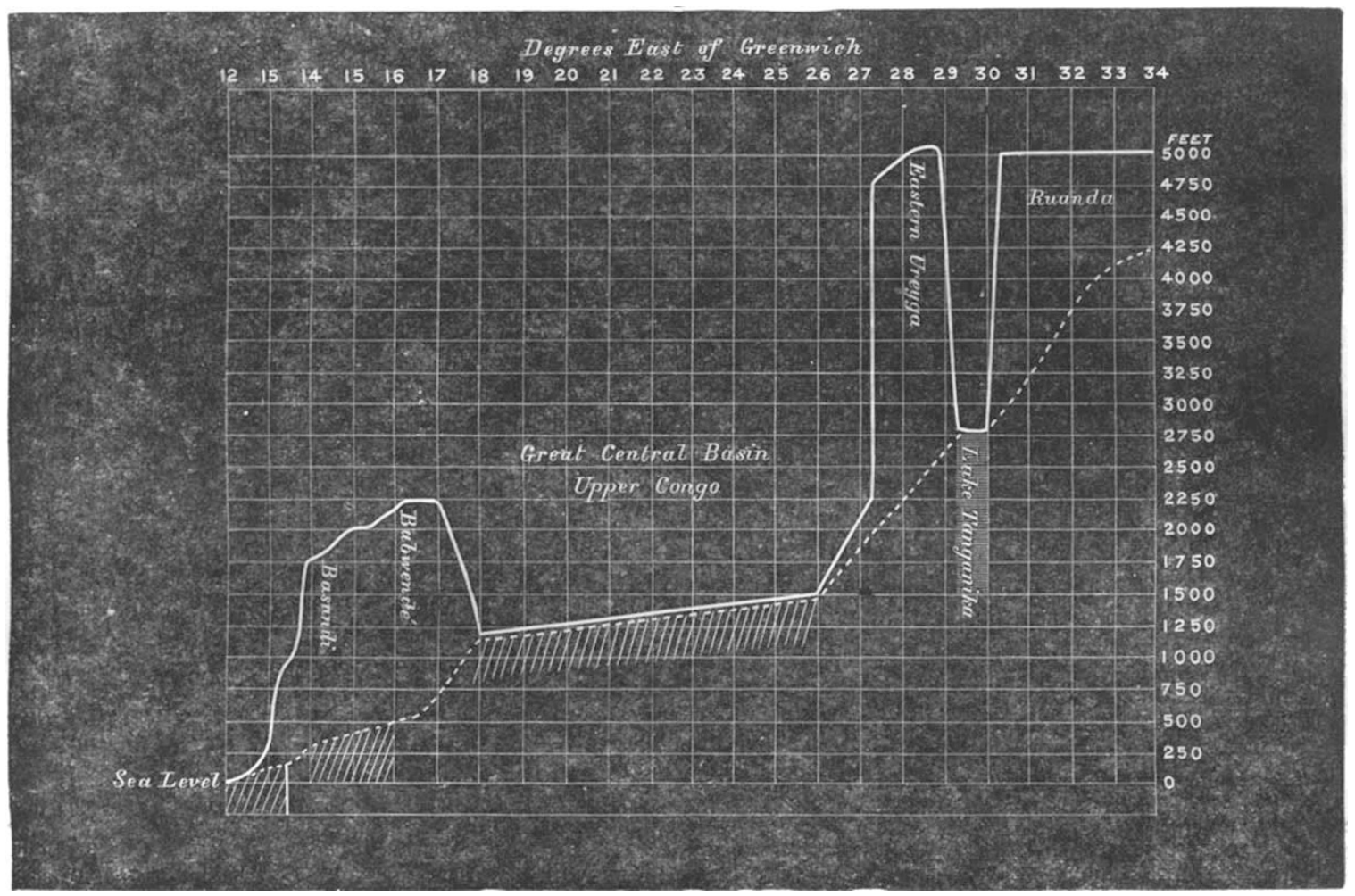

Fig. 6.-Profile of Country between the Sea and Ruanda, across the Congo Basin.?

almost 200,000 elephants in about 15,000 herds in the Congo basin, each carrying an average of 50 lbs. weight of ivory in bis head. Iron, he tells us, is abundant. The copper mines near Philippeville supply a large portion of Western Africa with their ingots. Plumbago is also abundant, and gold has been found in the beds of streams. Mr. Stanley gives a long list of tropical plants which abound in the Congo basin, while several European vegetables and fruits have been found to thrive. The Arabs, moreover, he tells us, are introducing the largegrained upland rice with extraordinary success. He adds many details concerning the trade, actual and possible, of the Congo region, his object, of course, being to show that here exists a magnificent field for the European trader, European capital, and European settlers.

Mr. Stanley's work is chiefly of value as telling the story of one of the most unique and interesting enterprises on record. This story he tells with abounding interest; there are many incidents throughout the volume told with the dramatic effect so well known to readers of "Through the Dark Continent." The work of founding the Free State has been well begun, but it is only the beginning ; for the sake of its complete success it is to be hoped that nothing may occur to sever Mr. Stanley's connection with it until it has been firmly established.

\section{NOTES}

THE Royal Society's conversazione, held on the evening of June Io, was a very great success, and those who had the labour of bringing the various things togethrr must have felt themselves amply rewarded by the great interest taken in them by the Fellows and guests, both ladies and gentlemen, who attended. Among the objects exhibited we may note the following:--Geological map (unpublished) of Palestine and
Arabia Petræa, exhibited by Prof. Edward Hull, F.R.S.; original drawings of the skeletal, digestive, and vocal organs of birds, made in the years $1842-46$, drawn and exhibited by Prof. W. K. Parker, F.R.S. ; Sketches of the eclipse of the moon, October 4,1884 , and a very beautiful series of sketches of the wonclerful sunsets and after-glows, painted and exhibited by Mr. W. Ascroft ; star-charting by photography (enlarged prints rom negatives made in 1883 and 1884 ), exhibited by Mr. A. A. 